Kwartalnik Młodych Muzykologów UJ

no. 47 (4/2020), 197-213

DOI 10.4467/23537094KMMUJ.20.048.13921

www.ejournals.eu/kmmuj

(iD https://orcid.org/oooo-0oo1-9456-498X

\title{
Antonina Wiatr
}

Grażyna and Kiejstut Bacewicz University of Music In Łódż

\section{Concerts of the Jewish Orchestra in the Łódź Ghetto during the Second World War}

\section{Abstract}

The article discusses concerts organised by the inhabitants of the Łódź Ghetto and their cultural context. My research focuses on concerts conducted by Teodor Ryder, with preserved posters and programmes used as my sources. The surviving concert reviews written in the ghetto contribute to a better understanding of these events. Analysis of source materials provides me with an opportunity to describe the musical life in the ghetto and discuss the role of music in the lives of its inhabitants.

\section{Keywords}

Łódź Ghetto, Holocaust, cultural life, World War II 
What did the concert activity of musicians in the Łódź Ghetto look like? It was a district of forced Jewish residence created in Łódź by the Germans. In this paper, based on the preserved documents, I attempt to show how the symphony orchestra operated in the Łódź Ghetto and what problems it had to face. Despite the terrible conditions, contact with art (music and poetry) provided people with a semblance of a fuller life. The study of concert posters makes it possible to present the repertoire of the ghetto's symphony orchestra in the context of Nazi musical propaganda during World War II. Analysis of concert life and its reception will also shed light on the role of music in the lives of the ghetto's inhabitants.

Kronika getta tódzkiego [Chronicle of the Łódź Ghetto] / Litzmannstadt Getto 1941-1944 is a unique document describing the day-to-day lives of the ghetto's inmates. An accurate commentary on the cultural life of the ghetto can be found in an entry of 9 June 1943:

The future reader will possibly react with disbelief to the presence in these reports of too frequent mentions of various performances and events and will probably conclude that the situation of the ghetto's population could not have been so tragic after all [...]. Many people in the ghetto naturally shake their heads [...] in the belief that the situation of Jews in the ghetto generally does not permit such a simplified view of social life. Nevertheless, closing those last channels of vitality and affirmation of life would mean stifling these downtrodden people's will to live [...] The chronicler would like to [...] declare to the future reader that the suffering of the ghetto did not become any less intense for the few happier moments we have had here. ${ }^{1}$

The chronicler addresses the future reader with surprising directness, highlighting one of the key aspects of the concert activity of that time: Music satisfied the 'hunger for life ${ }^{2}$ that the ghetto's residents still felt. It was an occasional pleasure, which, though it could in no way make up for all the hardships, nevertheless created

Cf. Kronika getta łódzkiego / Litzmannstadt Getto 1941-1944, 3, J. Baranowski et al., eds (2009), 267-269, entry for 9 June 1943.

2 A prisoner of the Warsaw ghetto, Ludwik Hirszfeld wrote in his post-war memoirs: 'Jews at that time still had a hunger for life. It found its expression in the activity of [...] theatres and concerts', L. Hirszfeld, Historia jednego życia (1946), 242. 
the semblance of normal life. Allowing oneself to attend literary soirées, revue spectacles, or symphonic concerts was thus a form of mental self-defence.

\section{The Place and Profile of Musicians of Jewish Origin in the German Cultural Policy}

In the 1930s, Germany adopted measures to eliminate people of Jewish origin from social life, including arts. Jewish musicians were forbidden to perform on the stage, and the concert repertoire began to be selected and limited. According to Hans Pfitzner, ${ }^{3}$ modernist Jewish composers were the ones responsible for the degeneration of art and the disintegration of the German nation. ${ }^{4}$ In most cases, however, those musicians had nothing to do with politics. In May 1938 Joseph Goebbels, the Minister of Propaganda of the Third Reich, delivered a speech on the subject of the German nation's 'musical superiority'. He emphasised the benefits of the Germans' outstanding musicality, which had allowed them to 'give [...] to humanity wonderful works of authentic music.' ${ }^{\prime}$ While expressing such faith in the crucial role of Aryan music, the authorities aimed at a clear separation of German from Jewish elements in musical works.?

Such a cultural policy built an atmosphere of resentment around the Jewish people, which led to their gradual elimination from social

3 A German composer and conductor with strong ideological ties to the Nazi Party. In his writings he promoted musical anti-Semitism. Cf. P. Frankin, 'Hans Pfitzner', https://www.oxfordmusiconline.com/grovemusic/ view/10.1093/ gmo/9781561592630.001.0001/omo-9781561592630-e-00ooo21537, accessed 15 Dec. 2020.

4 L. Hirsch, A Jewish Orchestra in Nazi Germany. Musical Politics and the Berlin Jewish Culture League (2010), 8.

5 Due to his Jewish origin, Arnold Schönberg, a leading dodecaphonist, found himself on the list of rejected composers of 'degenerate' music (entartete Musik). Interestingly, he had repeatedly expressed the hope that the success of his music would reinforce Germans in their hegemony among other European countries.

6 B. Drewniak, Kultura w cieniu swastyki (1969), 10.

7 Music by composers of Jewish origin, such as Felix Mendelssohn and Giacomo Meyerbeer, was not performed at concerts in Germany, although their works did not differ significantly from other works created by German composers in the same period. Cf. Hirsch, A Jewish Orchestra..., 29. 
life, and ultimately to the Holocaust. The figure of the Jewish composer or instrumentalist was presented in a pejorative light. Such artists were barred from taking part in cultural life and deprived of all sources of income. German musicians of Jewish origin who were no longer allowed to participate in official cultural life could become members of Jüdischer Kulturbund (Union of Jewish Culture). The repertoire of its orchestras was under strict supervision from the Nazi party. Jewish musicians were forbidden to perform music by German composers (first that of Richard Strauss and Richard Wagner, later also of Ludwig van Beethoven, Wolfgang Amadeus Mozart, and Joseph Haydn). At the same time, they were strongly encouraged to take up works by composers of Jewish origin. The purpose of such restrictions was to draw a sharp dividing line between Jewish and Aryan music and to 'protect' great music from being improperly performed. ${ }^{8}$

The German press propagated 'purely German' works with full conviction. The propaganda praised their artistic and political values and strongly emphasised the origins of Aryan composers as well as their patriotic or xenophobic attitudes ${ }^{9}$. Danuta Gwizdalanka notes that in propagandist analyses of German compositions the expected ideological undertones were attributed to elements of the music work: 'Sharp conflicts, manifesting themselves in strongly contrasted themes [...] should lead to the final heroic apotheosis, in order to put the audience into a state of elation. ${ }^{10}$ Among the most respected composers were Beethoven, Wagner, Johannes Brahms, and Richard Strauss.

The thus defined cultural policy clearly distinguished between the two repertoires, emphasised Germanic elements in the profiles of composers and anti-Semitism in the field of music studies. Paradoxically, this policy did not find a direct reflection in the musical scene of the Łódź Ghetto, which only proves the authorities' lack of interest in the ghetto's inmates rather than an intention to give them cultural 'freedom'.

Hirsch, A Jewish Orchestra..., 31-34.

9 D. Dennis, "Honor your German masters: The use and abuse of "classical" composers in Nazi propaganda', in: Journal of Political \& Military Sociology, 2 (30) (2002), 275.

10 D. Gwizdalanka, Muzyka i polityka (1999), 173. 


\section{Cultural Life in Pre-War Łódź}

At the beginning of the twentieth century, Łódź was a multicultural city, inhabited not only by Poles but also Jews, Germans, and Russians. Each of these minorities left its mark in the city's cultural life by organising amateur instrumental ensembles and choirs as well as creating music societies.

One of the most important cultural institutions in the city before the war was Łódź Music Society, officially established in 1898. It is an example of cooperation between representatives of the Polish, Jewish, and German nationalities. ${ }^{11}$ During the eight years of its activity, the Society organised symphonic and choral concerts, contributing to the development of musical life in the city. The Jewish amateur choir 'Hazomir', which had existed from 1899, transformed into the Jewish Music Society and largely took over the responsibilities of Łódź Music Society after the latter's collapse.

The Jewish Music Society organised choral and symphonic concerts, sometimes with the participation of soloists-instrumentalists. A symphony orchestra operated under the auspices of the Society from 1907, with Naum Podkeimer as its first conductor. Under his leadership, the orchestra played the Romantic repertoire as well as works by such composers as Felix Mendelssohn-Bartholdy, Henryk Wieniawski, and Jean Sibelius. Thanks to Saweł Zilberts, who held the post of the orchestra's conductor in 1903-1906 and 1914-1920, it also performed great sacred works by Joseph Haydn and Wolfgang Amadeus Mozart. In the years 1922-1932, the orchestra was led by Izrael Fajwiszys. He continued to promote the repertoire established by the previous conductor, which included large-scale vocal-instrumental works by Handel, Mendelssohn, and Beethoven. ${ }^{12}$

In February 1915, a group of musicians from Łódź led by conductor Tadeusz Mazurkiewicz formed the Łódź Symphony Orchestra. Most of its concerts were held in Łódź Concert House, also known as the Concert Hall or the Vogel Hall, after its founder and first owner Ignacy Vogel. ${ }^{13}$

\footnotetext{
A. Pellowski, Kultura muzyczna Łodzi do roku 1918 (1994), 224-234.

12 L. Błaszczyk, ‘Żydowskie Towarzystwo Muzyczne i Literackie Hazomir’, in Żydzi w kulturze muzycznej ziem polskich w XIX i XX wieku (2014).

${ }_{13}$ B. Pellowska-Chudobińska, 'Muzyczne dziedzictwo - projekt archiwum Filharmonii Łódzkiej im. Artura Rubinsteina', Archeion 113 (2012), 204-205.
} 
The pre-war orchestra was probably composed largely of musicians of Jewish origin. Bożena Pellowska-Chudobińska writes that before the war, two orchestras competed with each other in Łódź for several years: the 'Christian' one founded by the Christian Musicians' Union and the 'Jewish' Łódź Symphony Orchestra. ${ }^{14}$ The list of pre-war Łódź Symphony Orchestra members who lived in the ghetto under the German occupation is long. Unfortunately, it is not known exactly how many of them found employment in their own profession in the ghetto. Among many others, one can name flutist Mendel Ajzenman, violinists Rafał and Leon Kantor (the latter subsequently played the first violin in the Łódź Ghetto's orchestra), violinist Henryk Goldberg, bassist Dawid Kopp, and another violinist, Bronisława Rotsztat (later the soloist of many concerts held in the Łódź Ghetto and concertmaster of the Łódź Symphony Orchestra after the war). Two members of the Bajgelman musical family played in the orchestra as well: Dawid Bajgelman on the viola (he then frequently acted as conductor in the ghetto) and Szymon Bajgelman on the clarinet. ${ }^{15}$ From 1916, conductor Teodor Ry$\operatorname{der}^{16}$ also collaborated with this ensemble. He was strongly involved in the city's cultural life as a lecturer at the Helena Kijeńska-Dobkiewicz Music Conservatory and the music director of Łódź Opera Society. During the war, together with Bajgelman, he led the ghetto's symphony orchestra. The composer, journalist and music critic Felix Halpern ${ }^{17}$ was also associated with the Łódź Symphony Orchestra. His brilliant reviews in the city's newspapers concerning the repertoire, performers,

14 Pellowska-Chudobińska, 'Muzyczne dziedzictwo...', 207.

${ }_{15}$ For more on the musicians mentioned here, see: Błaszczyk, Żydzi w kulturze muzy$c z n e j . . .$, the entries for: Ajzelman Mendel, Kantor Rafał, etc.

16 Born in 1881, pianist and conductor. Following music studies, he worked with many European orchestras. In 1940, he was relocated to the ghetto with his wife, the German singer Ida Voth, who had converted to Judaism for the sake of her husband and of her own free will moved to live with him in the ghetto (though she could have avoided this fate because of her German descent). See: L. Błaszczyk, Dyrygenci polscy i obcy w Polsce działajacy w XIX i XX wieku (1964), 254-255.

17 Felix Halpern, born in 1866, was a pianist and teacher from Łódź, strongly associated with the musical life of the city. He was a board member of Łódź Music Society and served on the juries of piano competitions. During the war, he lived in the Łódź Ghetto, where he died in 1942. Cf. A. Stawiszyńska, 'Łódzka Orkiestra Symfoniczna czasów Wielkiej Wojny w recenzjach Felixa Halperna’, Acta Universitatis Lodziensis. Folia Linguistica, 20 (2013), 57-71. 
and the reception of pre-war concerts provide us with detailed knowledge of the city's cultural life.

The artistic initiatives undertaken in the Łódź Ghetto should thus be viewed from this historical and cultural perspective. In addition to the aforementioned symphonic concerts, chamber ensembles also performed in the ghetto, and street musicians strongly marked their presence. This article focuses exclusively on the analysis of concert activity in Łódź. Comparison of cultural initiatives known from ghettos established in different European cities is a subject for a separate study.

\section{The Ghetto in Occupied Łódź}

The Łódź Ghetto was the second-largest Jewish settlement in Poland after Warsaw. On 30 April 1940, its official borders were designated and closed. Mordechaj Chaim Rumkowski, a representative of the Jewish population, was appointed Chief Elder (Judenältester) of the Jewish Council of Elders by the German invaders. Its very strongly developed administration was a feature that distinguished the Łódź Ghetto from other Jewish districts in Poland. The ghetto became an important source of income for the German economy thanks to the functioning of workshops: ${ }^{18}$ sewing, shoemaking, metalworking, and others, which filled orders from German companies. In addition to exhausting work and dire housing standards, people suffered from hunger and cold. All this made living conditions in the ghetto profoundly inhumane.

This paper is based on historical documents collected and published in scientific studies or remaining in their original form and found in archives. One of the primary sources was the already mentioned Chronicle of the Eódź Ghetto, whose authors described many aspects of life, including cultural activities. Texts by Oskar Rosenfeld, a Prague journalist and writer deported to Łódź in the autumn of 1941, are of special value to this research. In addition to texts for the Chronicle, Rosenfeld also kept a diary where he noted down his reviews of symphonic concerts and other artistic events,

${ }_{18}$ Called resorty, i.e. departments, in the ghetto. 
written with great accuracy and musical expertise. The surviving concert posters and programmes likewise constitute a significant source of information about the repertoire, performers, and dates of concerts. ${ }^{19}$

\section{Cultural Life in the Łódź Ghetto}

Musical activity was taken up in the ghetto from the very start. The desire to give concerts may have resulted from both the artists' deep-rooted need for contact with music and from the mundane necessity to earn money. Before the official institutions responsible for the organisation of cultural life began to function, artists performed, among others, within the framework of pre-war institutions such as the 'Hazomir' Music Society. According to the documentation, their first concert took place on 30 October 1940, six months after the ghetto borders had been closed. ${ }^{20}$

Apart from performances by orchestras and choirs, private concerts were also organised in kitchens or other available venues. These were usually chamber music events or solo recitals. Even the Superior of the Elders of the Jews, Rumkowski, ${ }^{21}$ was sometimes invited to these occasions, which, however, did not have an official character; hence, unfortunately, they are rarely recorded in documents. There are also no performers' testimonies, which would offer us more accurate insights into the realities of artistic life than all kinds of essays and critics' reviews.

From 1941 onwards, artistic life was organised by the Department of Culture. The vast majority of the events were held in a pre-war cinema known as the Kulturhaus (the Cultural Centre) and located at 3 Krawiecka Street. The Department of Culture was part of the official administration of the ghetto, and its employees became officials. ${ }^{22}$

19 The documents I draw upon are available in: The Archives of the Institute for Jewish Research in New York (hereinafter as YIVO), RG-241/1036, RG-241/858; State Archive in Łódź, collection of the Chief Elder of the Jewish Council of Elders, shelf mark 2339.

20 Kronika..., 5, 304.

${ }^{21} \quad$ Kronika..., 1, 108-109, entry for 1 March 1941.

22 YIVO, RG-241/1036, a document listing the newly recruited officials; in the space for 'type of work' it says: 'singer-soloist' or simply 'musician'. 
As a result, a group of thirty to forty orchestra members and singers were provided with full-time employment; some of them, it seems, had previously been associated with the 'Hazomir' Music Society. At the end of 1941, many excellent artists were relocated from the Reich and Protectorate of Bohemia and Moravia to Łódź. They were conductors, composers, and soloists-instrumentalists. ${ }^{23}$ Unfortunately, only a tiny percentage of them could find employment in their profession in the Łódź Ghetto.

Bronisława Rotsztat, previously associated with the Łódź Symphony Orchestra, was one of those instrumentalists who maintained a busy and documented concert schedule. Her name frequently appears in the surviving programs of symphonic concerts held in Krawiecka Street. During her more than a year-long officially documented activity, the violinist performed at least once a month as an orchestra soloist, playing the greatest works of the violin literature, such as, among others, concertos by Mozart, Mendelssohn, Brahms, Henryk Wieniawski and Pyotr Tchaikovsky. ${ }^{24}$ Pianist Leopold Birkenfeld was another eminent virtuoso ${ }^{25}$ who was deported to Łódź at the end of 1941. Together with Kurt Behr, they frequently appeared on the official bills for concerts organised by the Culture Department.

Towards the end of 1942, the Kulturhaus ceased to be an independent institution, and the musicians had to find other employment. Due to the increasing number of transportations to camps, relocations, and the Wielka Szpera (Allgemeine Gehsperre) ${ }^{26}$ carried out in September, artistic activity ceased for several months. When

23 In the period between 16 October and 4 November 1941, twenty transports of Jews from Western Europe arrived in the Łódź Ghetto. Among the approximately twenty thousand people there were sixty musicians and singers, Cf. Kronika..., 1, 363 .

24 YIVO, RG-241/1036, Culture Haus; programmes of twenty-nine symphonic concerts performed between 26 March 1941 and 12 August 1942; the State Archive in Łódź, collection of the Chief Elder of the Jewish Council of Elders, shelf mark 2339, posters and announcements about concerts held at the Kulturhaus.

25 Viennese pianist, born in 1896. In May 1942 he was transported to Chełmno on the Ner and murdered there. Kronika..., 5, 281.

26 It was an action carried out by the Germans; the victims of which were children under 10 and the elderly over 65 , transported to a death camp. There was no person in the ghetto that was not devastated and affected by this tragedy. After the szpera, the ghetto's autonomy was reduced and it was actually transformed into a labour camp. 
it was resumed, the concerts were much rarer and took a different form. They were no longer the result of the Department of Culture's official activity. An entry from the Chronicle of the Łódź Ghetto from 24 November 1943 can again serve as a perfect commentary for these events.

No matter how depressing the life of the ghetto's inhabitants is, they do not want completely to give up all forms of cultural life. The closure of the Kulturhaus deprived the ghetto population of the remnants of their cultural and social life. Nevertheless, the persistence and vitality of the ghetto's people, hardened by countless blows, makes them keep looking for new opportunities to satisfy at least partly their hunger for culture. The need for contact with music is especially strong. Therefore, small centres dedicated to music-making have slowly been emerging, albeit [catering] only for the needs of one, rather higher class. Professional musicians and sometimes amateurs give concerts for small groups of guests. Chamber repertoire is played and sung. ${ }^{27}$

The desire of the ghetto's inhabitants to satisfy their 'hunger for culture' may be one of the arguments to support the thesis that artistic, and particularly musical activity was a form of resistance to the tragic realities of life. ${ }^{28}$ The order issued in January 1944 to confiscate musical instruments was a great tragedy for all artists. Many priceless instruments were 'purchased' at prices that did not correspond to even one-hundredth of their real value..$^{29}$ These instruments were later assigned for use by a Hitlerjugend music school, the municipal orchestra, and the Reichmusikkammer (Reich Chamber of Music).

${ }_{27}$ Kronika..., 3, 613, entry for 24 November 1943.

28 Shirli Gilbert presents a slightly different interpretation of this situation. She agrees that musical activity was an imitation of 'normal life' from the time before the war, but she believes that it cannot be referred to as spiritual resistance even in the broad sense, due to, among other things, the ghetto's multiculturalism and the lack of unification in the community. Cf. S. Gilbert, Music in the Holocaust. Confronting Life in the Nazi Ghettos and Camps (2005), 12.

29 Rywka Lipszyc refers to this situation in her diary. Her friend Lusia 'had to burn her violin (all instruments from the ghetto need to be given away) and from time to time she burst into tears'. Cf. R. Lipszyc, Dziennik z łódzkiego getta, ed. E. Wiatr (2017), 97, entry for 7 February 1944. 


\section{Symphonic Concerts and Their Significance}

The concerts at the Kulturhaus were usually conducted by Maestro Teodor Ryder. According to Tomasz Majewski, 'the sources mention at least four symphonic concerts under his baton. ${ }^{30} \mathrm{~A}$ more detailed analysis of the sources reveals not four but at least twenty-nine programmes of concerts led by this conductor..$^{31}$ They were held regularly on Wednesdays and Saturdays. Apart from Ryder, Dawid Bajgelman, who specialised in Jewish music and revues, also took his place on the conductor's podium. Oskar Rosenfeld writes about Ryder in his diary:

The bandmaster must not be underestimated, despite his modesty and self-restraint. [...] His movements are lively, his arms reach out far, not as in the case of the so-called 'no-nonsense' conductors who offer little of themselves, but instead try to attract the attention of even a large orchestra with short movements..$^{32}$

Thanks to his experience and competence, Maestro Ryder managed to maintain the symphony orchestra on a surprisingly high level, considering the living and working conditions in the ghetto. He led an ensemble composed mainly of musicians playing the strings, with a small addition of wind instruments. Since the orchestra was incomplete, the conductor was frequently forced to introduce changes in the orchestration of works; the parts of some of the unavailable instruments were assigned to the piano. ${ }^{33}$ Despite limited access to scores, the orchestra had an impressive repertoire. The question of restrictions imposed by the Germans regarding the repertoire of concerts in the Łódź Ghetto is ambiguous. In the Warsaw ghetto, the Germans allowed musicians to perform only 'Jewish' music, ${ }^{34}$ but it was an unwritten law and in effect

30 T. Majewski, 'Muzyka w getcie - acheronta movebo', https://www.centrumdialogu. com/muzyka-w-getcie-, accessed 12 Apr. 2020.

31 YIVO, RG-241/1036, Culture Haus; programmes of twenty-nine symphonic concerts performed between 26 March 1941 and 12 August 1942.

32 K. Radziszewska; E. Wiatr, eds, Oblicza getta. Antologia tekstów z getta łódzkiego (2018), 9.

33 Radziszewska, Wiatr, eds, Oblicza getta..., 10.

34 The situation was completely different in the German concentration camps, where the repertoire was chosen by SS-men; German songs or works of a nationalist character were enforced. Unlike in the Łódź Ghetto, the restrictions on the 
it was not respected. Precisely for this reason, however, the activity of that ghetto's Jewish Symphony Orchestra was suspended, albeit only after two years of work..$^{35}$ There are no surviving documents concerning restrictions imposed on musicians at the Łódź Ghetto. This does not prove that the situation of the orchestras in the ghettos of Warsaw and Łódź was quite different. It rather reflects the German authorities' lack of interest in the music life of the Łódź Ghetto as long as peace was maintained, and the personnel of the workshops continued to produce goods for the needs of the economy of the Third Reich.

Teodor Ryder was responsible for programming the concerts held in the Łódź Kulturhaus..$^{36}$ The repertoire ${ }^{37}$ consisted mainly of Romantic, sometimes Classical or even twentieth-century music. In addition to such famous Classics and Romantics as Wolfgang Amadeus Mozart, Ludwig van Beethoven, Carl Maria von Weber, Franz Liszt, Pyotr Tchaikovsky, and Antonín Dvořák, on the posters we find the names of world-famous Jewish composers (Joseph Achron, Jacques Fromental Halévy) and those living in the ghetto (Moyshe Darguzhanski vel Maurycy Dargużański, ${ }^{38}$ Dawid Bajgelman). Excerpts from Christoph Willibald Gluck's opera Iphigénie en Tauride from the early Classical period ${ }^{39}$ were an exception from this predominantly Romantic literature. We know from existing accounts that Maestro Ryder wanted to include other well-known works by Jewish composers in his repertoire, for instance by Gustav Mahler and Arnold Schönberg. Still, it proved impossible due to limited access to scores. ${ }^{40}$ Opera overtures or individual movements of symphonies were often performed, as also

repertoire were strictly observed in the camps. Cf. A. Kulisiewicz, 'Muzyka i pieśń jako współczynnik samoobrony psychicznej więźniów w obozach hitlerowskich', Przeglad Lekarski, 1 (34) (1977), 69.

35 M. Fuks, Muzyka Ocalona. Judaica polskie (1989), 169.

${ }_{36}$ Radziszewska, Wiatr, eds, Oblicza getta..., 10.

37 My analysis of the repertoire is based on concert posters kept at YIVO, RG241/1036, Culture Haus; programmes of twenty-nine symphonic concerts performed between 26 March 1941 and 12 August 1942.

${ }_{38}$ Born in 1867, conductor, teacher, and music reviewer. From around 1895 he was active in Łódź. He was a choirmaster in the Great Synagogue, and he also taught singing in Jewish schools. Cf. L. Błaszczyk, Żydzi w kulturze muzycznej..., 53.

39 One of the documents lists, most likely by mistake, a non-existent overture by Bach entitled Hamlet. However, this is hardly a proof of the presence of Baroque music in the repertoire, but most likely yet another example taken from Romantic literature. The composer of an overture of the same title is Pyotr Tchaikovsky. YIVO, RG-241/858, reportage by O. Rosenfeld, 'Konzert im Kulturhaus'. 
were small-scale forms arranged for orchestra, probably because of their short duration. The vast majority of the concert programmes thus consisted of numerous (sometimes as many as ten) short pieces. Long forms, such as complete symphonies or instrumental concertos with orchestral accompaniment, were mostly presented during the occasional 'single-composer' evenings (the Beethoven-Abend, Mendelssohn-Abend, etc). Performing favourite highlights from an opera or operas by a given composer was also popular. The posters feature such names as Giacomo Meyerbeer, Gioacchino Rossini, Stanisław Moniuszko, Léo Delibes, and Giacomo Puccini. The most frequently performed opera composer was Halévy and excerpts from his opera La Juive.

Dawid Bajgelman conducted a slightly different repertoire. While Ryder's concerts abounded in well-known and highly regarded Romantic works, Bajgelman based his programmes on 'light' operetta and dance pieces. French (Émile Waldteufel), Hungarian (Imre Kálmán), and even Japanese (Mitsuzou Yoshimoto) composers can be named here. The concerts conducted by this artist also featured numerous Jewish songs written in the ghetto (including some composed by Bajgelman himself).

\section{Concert Repertoire Analysis: The Educational Role of Music}

Curiously enough, Richard Strauss and Richard Wagner were included in the programmes of the ghetto concerts. ${ }^{41}$ What such programming policy depended on and whether the musicians or the audience were aware of the political involvement of these composers and their music is difficult to determine. ${ }^{42}$

${ }^{41}$ YIVO, RG-241/1036, Culture Haus; programmes of twenty-nine symphonic concerts performed between 26 March 1941 and 12 August 1942.

42 In this context one might recall the situation that took place in 1904 in New York, when Wagner's Parsifal was staged in Yiddish in one of the Jewish theatres. Inappropriate as this may seem to us now, a researcher explains that in the early twentieth century Jewish audiences indeed enjoyed listening to Wagner's music. The composer's anti-Semitic writings were either unknown or ignored. Parsifal's religious overtones were also no obstacle to the positive reception of this work. Cf. D. Levy, 'Parsifal in Yiddish? Why not?', The Musical Quarterly, 2 (97) (2014). 
During one of the 'single-composer evenings' on 3 June 1942, the Egmont Overture Op. 84, Violin Concerto in D major Op. 61, and Symphony No. 1 in $C$ major Op. 21 by Ludwig van Beethoven were performed. The reception of this composer's music in the Third Reich is an interesting subject. German politicians viewed Beethoven's music as a reflection of the ideology they promoted. They paid particular attention to the heroic and 'valiant' elements of his output. To Nazi musicologists, Symphony No. 5 in C minor Op. 67 symbolised the German nation's struggle for survival and its successful quest for a Führer. ${ }^{43}$

It seems, however, that this music carries much more significance than what was acknowledged by the Nazi propaganda. It cannot be reduced to any single ideology and assigned to one nation; it was not destined for the amusement of the chosen few. Beethoven's music (as that by many other composers) could delight at the same time the cultural elites of Berlin and the poor inhabitants of the Jewish district of Łódź. Beethoven is one of the countless examples of music's ability to transcend linguistic and ideological boundaries and transmit much more meaning than the written and spoken word. Evidence of this can be found in Oskar Rosenfeld's diary entry concerning a performance by the ghetto's orchestra of Beethoven's Symphony No. 5 in C minor:

Even in the concert halls of major European cities, the audiences are not so evidently moved as they are here, in the ghetto. The interpretation of the third movement as a fugue that places the highest demands on the listeners' musical awareness was met with great understanding. ${ }^{44}$ As usual with Beethoven's final phrases, the freedom theme caused a massive reaction and murmur in the hall. [...] One could almost physically sense the vision of the future salvation. ${ }^{45}$

It is a great paradox that in the same works of music which the Germans saw as evidence of the greatness, strength, and uniqueness of their own nation, the musicians from the Łódź Ghetto were

43 D. Dennis, Beethoven in German Politics, 1870-1989 (1996), 151.

${ }_{44}$ According to the Bildung concept, compositions by Bach, Haydn, Mozart, and Beethoven are considered valuable not only for aesthetic reasons, but also because of their role in the upbringing, education and formation of the listeners' character. Cf. S. Cahn, 'A German-Jewish Tradition of Bildung and Its Imprint on Composition and Music Theory', The Musical Quarterly, 4 (101) (2018), 492.

45 Radziszewska, Wiatr, eds, Oblicza getta..., 8. 
able to discover a longing for freedom and the hope for imminent rescue. In his report from a concert held on 8 July 1942, Rosenfeld mentions another aspect of the influence of music on people in the ghetto:

In the Kulturhaus, the appropriate selection of programmes makes it possible to carry out the educational task of forming [human] characters; naturally [it happens] only gradually, with a lot of patience and understanding for the ghetto soul. If it had not been for this element, the musical performances in the Kulturhaus could be more or less disregarded. Ghetto inmates will not become weary as long as they feel the need to listen to music. During concerts, they are capable of the most wonderful spiritual elation. Their behaviour [...] allows one to hope that the passion for artistic values will remain undiminished. ${ }^{46}$

Unlike the revues ${ }^{47}$ and concerts of light music conducted by Bajgelman, the symphonic concerts afforded the audience an opportunity to experience more serious and mature art, which offered meaningful emotional experience. These artistic events satisfied the human need for beauty that was still alive in the ghetto's population. This was reflected, among others, in the unwavering interest in concerts held twice a week in a hall seating four hundred. In the above-quoted fragment, the author draws attention to the educational role of symphonic concerts. The idea of character formation entails the moral, emotional, and social education of individuals. In this case, it could also mean teaching them to adjust to the terrible conditions of life in the ghetto and to develop psychological self-defence that could protect them from the most profound despair..$^{8}$ This, according to Rosenfeld, was one of the most important goals of the Kulturhaus.

46 YIVO, RG-241/858, O. Rosenfeld, 'Kulturhaus-Konzerte'.

47 A revue is a stage performance combining an operetta and a skit, with elements of improvisation and the singing of songs written in the ghetto. On the unique characteristics of the revues staged in the Łódź Ghetto, see the entry for 'Revue', in K. Radziszewska et al., eds,,Encyklopedia getta (2014), 175.

48 Similar thoughts on the role of music in people's lives were formulated also in other Jewish ghettos. For Wiktor Ullmann, a composer from Theresienstadt Ghetto, art was a form of spiritual opposition and a form of escape from reality. By overcoming the hardships of daily life, he strove to constantly develop and shape his own character. Cf. S. Cahn, 'A German - Jewish Tradition...', 484-485. 


\section{Bibliography}

\section{Unpublished sources}

Baranowski, J. et al., eds., Kronika getta łódzkiego / Litzmannstadt Getto 1941-1944, 1-5 (Wydawnictwo Uniwersytetu Łódzkiego: Łódź, 2009). Institute for Jewish Research in New York (YIVO), RG-241/1036; RG$241 / 858$.

The State Archive in Łódź, collection of the Chief Elder of the Jewish Council of Elders, shelf mark 2339, posters and announcements about concerts held in the Kulturhaus (materials available at www.szukajwarchiwach.pl).

\section{References}

Błaszczyk, L., Dyrygenci polscy i obcy w Polsce działający w XIX i XX wieku (PWM: Kraków, 1964).

Błaszczyk, L., Żydzi w kulturze muzycznej ziem polskich w XIX i XX wieku (Stowarzyszenie Żydowski Instytut Historyczny w Polsce: Warszawa 2014).

Cahn, S., 'A German - Jewish Tradition of Bildung and Its Imprint on Composition and Music Theory', The Musical Quarterly, 4 (101) (2018).

Dennis, D., Beethoven in German Politics, 1870-1989 (Yale University Press: New Haven, 1996).

Dennis, D., 'Honor your German masters: The use and abuse of „classical" composers in Nazi propaganda', Journal of Political \& Military Sociology, 30, No. 2. (2002).

Drewniak, B., Kultura $w$ cieniu swastyki (Wydawnictwo Poznańskie: Poznań, 1969).

Franklin, P., 'Hans Pfitzner', Grove Music Online, https://www.oxfordmusiconline.com/grovemusic/view/10.1093/gmo/9781561592630.001.00o1/ omo9781561592630-e-ooooo21537, accessed 15 December 2020.

Fuks, M., Muzyka Ocalona. Judaica polskie (Wydawnictwa Radia i Telewizji: Warszawa, 1989).

Gilbert, S., Music in the Holocaust. Confronting Life in the Nazi Ghettos and Camps (Clarendon Press: Oxford, 2005).

Gwizdalanka, D., Muzyka i polityka (PWM: Kraków, 1999). 
Hirsch, L., A Jewish Orchestra in Nazi Germany. Musical Politics and the Berlin Jewish Culture League (The University of Michigan Press: Michigan, 2010).

Hirszfeld, L., Historia jednego życia (Wydawnictwo Literackie: Warszawa, 1946).

Kulisiewicz, A., 'Muzyka i pieśń jako współczynnik samoobrony psychicznej więźniów w obozach hitlerowskich', Przeglad Lekarski, 1 (34) (1977).

Levy, D., 'Parsifal in Yiddish? Why not?', The Musical Quarterly, 2 (97) (2014).

Lipszyc, R., Dziennik z łódzkiego getta, E. Wiatr, ed. (Austeria: Kraków, 2017).

Majewski, T., 'Muzyka w getcie - acheronta movebo', https://www.centrumdialogu.com/muzyka-w-getcie-, accessed 10 April 2020.

Pellowska-Chudobińska, B., 'Muzyczne dziedzictwo - projekt archiwum Filharmonii Łódzkiej im. Artura Rubinsteina', Archeion, 113 (2012).

Pellowski, A., Kultura muzyczna Łodzi do roku 1918 (Papier-Service: Łódź, 1994).

Radziszewska, K., et al., eds, Encyklopedia getta (Wydawnictwo Uniwersytetu Łódzkiego: Łódź, 2014).

Radziszewska, K., Wiatr, E. eds, Oblicza getta. Antologia tekstów z getta łódzkiego (Wydawnictwo Uniwersytetu Łódzkiego: Łódź, 2018).

Stawiszyńska, A., 'Łódzka Orkiestra Symfoniczna czasów Wielkiej Wojny w recenzjach Felixa Halperna', Acta Universitatis Lodziensis. Folia Linguistica, 20 (2013). 